\title{
PENGHAMBATAN FRAKSI FUKOIDAN RUMPUT LAUT COKELAT (Sargassum polycystum DAN Turbinaria conoides) TERHADAP a-AMILASE DAN a-GLUKOSIDASE
}

\author{
Widya Puspantari ${ }^{1}$, Feri Kusnandar ${ }^{2}$, Hanifah Nuryani Lioe ${ }^{2}$, Noer Laily ${ }^{1}$ \\ ${ }^{1}$ Pusat Teknologi Agroindustri, Badan Pengkajian dan Penerapan Teknologi, \\ Jalan M.H. Thamrin Kota Jakarta Pusat, Jakarta 10340 \\ ${ }^{2}$ Departemen Ilmu dan Teknologi Pangan, Fakultas Teknologi Pertanian, Institut Pertanian Bogor, \\ Kampus IPB Dramaga, Bogor 16680 \\ *Penulis Korespondensi: fkusnandar@apps.ipb.ac.id
}

Diterima: 20 Januari 2020/ Disetujui: 30 April 2020

Cara sitasi: Puspantari W, Kusnandar F, Lioe HN, Laily N. 2020. Penghambatan fraksi fukoidan rumput laut cokelat (Sargassum polycystum dan Turbinaria conoides) terhadap a-amilase dan a-glukosidase. Jurnal Pengolahan Hasil Perikanan Indonesia. 23(1): 122-136.

\begin{abstract}
Abstrak
Fukoidan merupakan polisakarida tersulfat dalam rumput laut cokelat yang memiliki aktivitas biologis, di antaranya sebagai antidiabetes. Penelitian ini bertujuan untuk menentukan kemampuan fukoidan dari rumput laut cokelat (Sargassum polycystum dan Turbinaria conoides) sebagai antidiabetes; yaitu dalam menghambat aktivitas $\alpha$-amilase dan $\alpha$-glukosidase secara in vitro. Kemampuan penghambatan enzim dievaluasi dari ekstrak kasar fukoidan, hasil fraksinasi dengan membran ultrafiltrasi (10 dan $30 \mathrm{kDa})$, dan kromatografi filtrasi gel. Ekstrak kasar fukoidan $(1 \mathrm{mg} / \mathrm{mL})$ dari S. polycystum hasil ekstraksi asam, dan dari T. conoides hasil ekstraksi air menunjukkan aktivitas penghambatan terhadap a-amilase dan a-glukosidase yang tertinggi. Fraksi dengan berat molekul $>30 \mathrm{kDa}$ hasil ultrafiltrasi ekstrak fukoidan dari $S$. polycystum dan T. conoides (pada konsentrasi $50 \mathrm{mg}$ ekstrak/3,0 mL akuabides) menunjukkan aktivitas penghambatan yang rendah terhadap $\alpha$-amilase (16,88\% dan 9,67\%), tetapi tinggi terhadap a-glukosidase $(99,06 \%$ dan 65,97\%). Fraksinasi dengan kromatografi filtrasi gel menunjukkan adanya senyawa aktif dalam fraksi fukoidan yang memiliki aktivitas penghambatan yang tinggi terhadap a-glukosidase, yaitu fraksi dengan berat molekul 30-70 kDa untuk S. polycystum dan $>70 \mathrm{kDa}$ untuk T. conoides. Penelitian ini menunjukkan bahwa fraksi fukoidan dari $S$. polycystum dan T. conoides memiliki kemampuan penghambatan terutama terhadap $\alpha$-amilase dan $\alpha$-glukosidase, dan berpotensi sebagai antidiabetes.
\end{abstract}

Kata kunci: antidiabetes, berat molekul, fukoidan, ultrafiltrasi

\section{The Inhibition of Fucoidan Fraction from Sargassum polycystum and Turbinaria conoides to $\alpha$-Amylase and $\alpha$-Glucosidase}

\begin{abstract}
Fucoidan is a sulphated polysaccharide found in brown seaweed exhibiting a biological activity, such as antidiabetic. This study aimed to determine the ability of fucoidan extracted from Sargassum polycystum and Turbinaria conoides as antidiabetic through in vitro $\alpha$-amylase and $\alpha$-glucosidase inhibition activities. The inhibitory activity was evaluated from the crude extracts of fucoidan as well as fractions obtained from ultrafiltration membrane (10 and $30 \mathrm{kDa}$ ), and gel filtration chromatography. The crude fucoidan from acid extraction from $S$. polycystum and that of from water extraction of T. conoides (at concentration of 50 $\mathrm{mg}$ extract/3.0 mL aquabidest) showed the highest inhibitory activities on $\alpha$-amylase and $\alpha$-glucosidase. Fucoidan fractions with $>30 \mathrm{kDa}$ from $S$. polycystum and T. conoides showed a low inhibitory activity against $\alpha$-amylase $(16.88 \%$ and $9.67 \%)$, but a high inhibition activity against $\alpha$-glucosidase $(99.06 \%$ and $65.97 \%$ ). Gel filtration chromatography revealed active compounds in fucoidan against $\alpha$-glucosidase, i.e. fractions with molecular weights of 30-70 kDa for S. polycystum and $>70 \mathrm{kDa}$ for T. conoides. This research exhibited that fucoidan fraction from S. polycystum and T. conoides had inhibition activity to a-amylase and a-glucosidase and potentially had antidiabetic effect.
\end{abstract}

Keywords: antidiabetic, fucoidan, molecular weight, ultrafiltration 


\section{PENDAHULUAN}

Fukoidan merupakan polisakarida yang memiliki struktur kimia dan berat molekul yang bervariasi. Struktur kimia fukoidan disusun oleh fukosa dan monosakarida lain (di antaranya manosa, xilosa, glukosa, galaktosa dan asam uronik) yang dihubungkan dengan ikatan glikosidik $\alpha(1,2), \alpha(1,3)$, dan atau $\alpha(1$, 4), serta gugus sulfat (Zvyagintseva et al. 2003; Lim et al. 2016). Penelitian terdahulu menunjukkan kemampuan fukoidan sebagai antioksidan (Sinurat dan Maulida 2018), antikoagulan (Sinurat et al.2011), antidiabetes (Kim et al. 2012; Wang et al. 2015; Lin et al. 2017), anti-inflamasi (Lee et al. 2013) dan proangionik (Yin 2013).

Struktur fukoidan memiliki gugus sulfat yang berbeda-beda dan bioaktivitas dari fukoidan dihubungkan dengan peranan gugus tersebut (Wang et al. 2010; Ale et al. 2011, Qu et al. 2014); Sinurat dan Kusumawati 2017). Sebagai contoh, uji bioaktivitas fukoidan dari Ecklonia kurome sebagai antikoagulan bergantung pada kandungan sulfatnya. Kandungan sulfat yang tinggi menghasilkan bioaktivitas yang lebih tinggi sebagai anti koagulan dibandingkan fukoidan dengan kandungan sulfat lebih rendah $(\mathrm{Qu}$ et al. 2014).

Fukoidan juga memiliki berat molekul yang berbeda dengan rentang yang lebar, di antaranya $7 \mathrm{kDa}$ (Zvyagintseva et al. 2003),

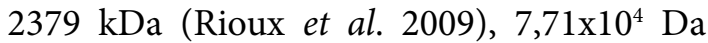
(Sinurat et al. 2011), dan $1 \times 10^{5} \mathrm{kDa}$ (Vo dan Kim 2013). Fukoidan yang berasal dari mikroalga dengan spesies, musim panen, dan kondisi iklim memiliki berat molekul yang berbeda (Li et al. 2006; Sinurat et al. 2011; Wang et al. 2019). Metode ekstraksi juga memengaruhi berat molekul fukoidan. Ekstraksi dengan air menghasilkan fukoidan dengan berat molekul yang besar, sedangkan ekstraksi dengan asam $(\mathrm{HCl})$ menghasilkan fukoidan dengan berat molekul yang kecil (Junaidi 2013; Sinurat dan Kusumawati 2017; January et al. 2019). Berat molekul fukoidan juga memengaruhi bioaktivitasnya, di antaranya sebagai antioksidan (0,8-10 $\mathrm{kDa}$ ) (Zhao et al. 2004; Yuan et al. 2015), antikoagulan (10-77 kDa) (Nishino et al. 1991; Sinurat et al. 2011; Wang et al., 2019), antiobesitas (0,8 kDa) (Lin et al. 2017), antidiabetes (5-30 kDa) (Kim et al. 2012; Chin et al. 2014; Wang et al. 2019), dan pro-angionik (15-20 kDa) (Yin 2013; Marinval et al. 2016). Berat molekul yang berbeda menunjukkan senyawa fukoidan yang berbeda, dan tentunya struktur senyawanya berbeda yang dapat memengaruhi bioaktivitasnya.

Di antara sumber fukoidan adalah rumput laut (Descamps et al. 2006). Jenis rumput laut yang mengandung fukoidan di antaranya adalah Sargassum sp., Turbinaria sp., dan Padina sp. (Sinurat et al. 2015), Cladosiphon okamuranus, Kjellmaniella crassifolia dan S. horneri (Ajisaka et al. 2016), dan Undaria pinnatifida (Synytsya et al. 2010). Fukoidan dari rumput laut tersebut memiliki potensi sebagai senyawa antidiabetes. Penelitian yang mengkaji potensi fukoidan dari rumput laut cokelat, khususnya $S$. polycystum dan T. conoides, khususnya sebagai antidiabetes, belum banyak dilaporkan. Perbedaan jenis rumput laut, dan lokasi pertumbuhannya dapat memengaruhi kandungan dan aktivitas fukoidan sebagai antidiabetes (Matanjun et al. 2009; Tapotubun 2018). Berat molekul dan gugus sulfat dari ekstrak fukoidan dari kedua rumput laut cokelat tersebut yang berkontribusi terhadap bioaktivitas antidiabetes juga belum banyak dilaporkan. Fraksi fukoidan dapat diperoleh dari esktrak fukoidan tersebut dengan cara ultrafiltrasi atau penyaringan molekuler yang diikuti dengan fraksinasi dengan kromatografi filtrasi gel. Fraksi fukoidan yang memiliki berat molekul lebih rendah memungkinkan memiliki jumlah gugus sulfat yang lebih sedikit, akan tetapi bioaktivitas dari fraksi fukoidan ini masih belum diketahui.

Potensi fukoidan sebagai antidiabetes dapatdiukurdarikemampuannyamenghambat aktivitas $\alpha$-amilase dan $\alpha$-glukosidase dalam memecah karbohidrat menjadi gula sederhana (Febriansyah et al. 2013). Kim et al. (2015) melaporkan fukoidan dengan berat molekul sedang $(637 \mathrm{kDa})$ memiliki aktivitas penghambatan $\alpha$-amilase, tetapi fukoidan dengan berat molekul besar $(>2000 \mathrm{kDa})$ dan berat molekul kecil $(<43 \mathrm{kDa})$ tidak memiliki aktivitas penghambatan terhadap $\alpha$-amilase. Fukoidan yang berasal dari Fucus vesiculosus 
menunjukkan kemampuan menghambat aktivitas $\alpha$-glukosidase dengan nilai $\mathrm{IC}_{50} 67,9$ $\mu \mathrm{g} / \mathrm{mL}$ (Shan et al. 2016). Menurut Hardoko et al. (2014), fraksi fukoidan dari S. duplicatum dan T. decurens memiliki aktivitas antidiabetes dengan menghambat aktivitas a-glukosidase. Fukoidan dari S. wightii juga menunjukkan aktivitas penghambatan $\alpha$-glukosidase sebesar $71 \%$ pada konsentrasi $250 \mu \mathrm{g} / \mathrm{mL}$ dan nilai $\mathrm{IC}_{50}(132,9 \mu \mathrm{g} / \mathrm{mL})$ (Vinoth et al. 2015).

Penelitian ini bertujuan untuk menentukan bioaktivitas fraksi fukoidan yang paling aktif yang diperoleh dari ultrafiltrasi dan kromatografi filtrasi gel dari ekstrak kasar fukoidan yang berasal dari rumput laut cokelat (S. polycystum dan T. conoides) sebagai antidiabetes secara in vitro, serta mengetahui berat molekul dan kadar sulfatnya.

\section{BAHAN DAN METODE Bahan dan Alat}

Bahan utama yang digunakan dalam penelitian ini adalah rumput laut cokelat jenis S. polycystum dan T. conoides dari Pulau Tidung Kepulauan Seribu. Sampel rumput laut diambil pada daerah pasang surut air laut pada beberapa lokasi (jarak sekitar $100 \mathrm{~m}$ dari pinggir pantai pada kedalaman dasar laut 1,0$1,5 \mathrm{~m})$. Rumput laut yang dipilih adalah yang sudah cukup tua dengan warna cokelat mudacokelat tua dengan ukuran talus rata-rata $67 \times 12 \mathrm{~cm}^{2}$ dan ukuran daun rata-rata $3,0 \times 0,5$ $\mathrm{cm}^{2}$.

Bahan kimia yang dibutuhkan untuk analisis diantaranya adalah $\mathrm{HCl}$ (SigmaAldrich, AS), $\mathrm{NaOH}$ (Sigma-Aldrich, Jerman), $\mathrm{CaCl}_{2}$ (Sigma-Aldrich, AS), bufer $\mathrm{Na}_{3} \mathrm{PO}_{4}$ (Sigma-Aldrich, AS), $\mathrm{Na}_{2} \mathrm{SO}_{4}$ (Sigma-Aldrich, US), $\mathrm{NaH}_{2} \mathrm{PO}_{4}$ (Sigma-Aldrich, AS), $\mathrm{BaCl}_{2}$ (Sigma-Aldrich, AS), KBr (Sigma-Aldrich, AS), $\mathrm{H}_{2} \mathrm{SO}_{4}$ pekat, etanol PA 99,9\% (Merck, Jerman), aseton (Sigma-Aldrich, Jerman), metanol (Sigma-Aldrich, Jerman), kloroform (Sigma-Aldrich, Jerman), gelatin (SigmaAldrich, Jerman), dan fenol (Merck, Jerman). Seluruh bahan kimia yang digunakan tersebut adalah analytical grade. Bahan lainnya adalah pati kentang (S2004, Sigma-Aldrich, Jerman), porcine pancreatic amylase (Sigma A3176, AS), a-glukosidase dari Bacillus stearothermophilus (Sigma G3651-250 UN, Jerman), glucobay
(50 mg acarbose, Bayer Healthcare, Indonesia), asam 3,5-dinitrosalisilat (DNS), 4-nitrophenyl $\beta$-D-glucopyranoside (PNPG), L-fukosa (Sigma F2252, AS), Regenerated Cellulose 10000 MWCO dan 30000 MWCO ultrafiltration membranes (Millipore, Irlandia), dekstran berat molekul $70 \mathrm{kDa}$ dari Leuconostoc spp. (Sigma 31390, Jerman) dan Sephadex G-75 (Pharmacia, Swedia).

Peralatan yang digunakan dalam penelitian ini adalah oven kabinet (kapasitas $20 \mathrm{~kg}$, Memmert UN260, Jerman) dengan loyang pengering $\left(44,5 \times 55 \times 3,5 \quad \mathrm{~cm}^{3}\right)$, penepung (Dust Collecting Fine Crushing Set, Jiangyin Hongda Powder Equipment, China), pemanas magnetik (C-Mag HS 7, IKA, China), timbangan analitik (ABS 220-4, Kern, Jerman), termometer, penangas air bergoyang (Wisd, Daihan Scientific, China), sieve shaker 80 mesh (RX863 serial I2950, W.S Tyler, USA), freeze dryer (Snijder, Belanda), kertas saring Whatman no 2, planktonet nilon (Dynamic Aqua Supply, Kanada), tabung ultrafiltrasi membran 10 dan $30 \mathrm{kDa}$ (Ultracel-10 $\mathrm{K}$ and Ultracel-30 K, Millipore, Irelandia), sentrifus (Legend XTR, Thermo Scientific, AS).

Peralatan yang digunakan untuk analisis adalah kolom kromatografifiltrasigel(diameter $x$ tinggi $\left(1,5 \times 60 \quad \mathrm{~cm}^{2}\right)$, spektrofotometer UV-VIS Evolution 220 (Thermo Scientific $^{\mathrm{rm}}$, AS), refraktometer (Atago PR-210, Jepang), sentrifuse (Thermo Scientific Legend XTR, USA), Fourrier Transform Infared (FTIR, Nicolet iS10 Thermofisher, AS), elisa reader (Multiskan Ascent, Thermo, USA) dan fraction collector (Akta Prime, Amersham Biosciences, Inggris).

\section{Metode Penelitian Persiapan dan karakterisasi tepung rumput laut}

Rumput laut basah (S. polycystum dan $T$. conoides) sebanyak $25 \mathrm{~kg}$ dicuci dengan air laut agar tidak cepat busuk sebelum dimasukkan ke dalam kotak penyimpanan. Rumput laut ditiriskan dan dicuci dengan air tawar untuk menghilangkan pasir dan kotoran yang menempel, dan dipotong dengan ukuran $1 \mathrm{~cm}$ kemudian dikeringkan dengan oven pada suhu $50^{\circ} \mathrm{C}$ selama 18 jam. Pada saat pengeringan, setiap loyang diisi dengan \pm 
1300 g rumput laut basah dengan ketebalan 2 $\mathrm{cm}$. Rumput laut yang sudah kering digiling menjadi bubuk kemudian, diayak pada ukuran 80 mesh (Hjelland et al. 2012). Sampel tepung rumput laut dihitung rendemen dan dianalisis kadar air, abu, protein, lemak, total karbohidrat, dan serat pangan (AOAC 2005).

\section{Ekstraksi fukoidan kasar}

Bubuk rumput laut $(5,0 \mathrm{~g})$ direndam dalam campuran $\mathrm{MeOH}: \mathrm{CHCl}_{3}: \mathrm{H}_{2} \mathrm{O}$ (4:2:1) (Sinurat 2011) pada suhu ruang selama 3 jam untuk menghilangkan lemak, pigmen dan komponen dengan berat molekul yang lebih rendah. Sampel kemudian disaring dengan plankton net 500 mesh, dibilas dengan aseton dan dikeringkan. Fukoidan diekstrak dengan dua metode, yaitu dengan pelarut air dan asam.

Metode ekstraksi dengan pelarut asam dilakukan dengan cara merendam sampel dalam $\mathrm{HCl} 0,1 \mathrm{M}(1: 10)(\mathrm{b} / \mathrm{v})$, diaduk selama 24 jam pada suhu ruang, dan disaring. Filtrat kemudian dinetralkan dengan $0,1 \mathrm{M} \mathrm{NaOH}$ dan diendapkan dengan tiga kali volume etanol. Endapan dilarutkan kembali dengan air dan ditambahkan $\mathrm{HCl}$ 0,1 M sampai $\mathrm{pH} 2$ (Synytsya et al. 2010), lalu diendapkan dengan larutan $\mathrm{CaCl}_{2}$ jenuh, disentrifusi $\left(4374 \times g 5^{\circ} \mathrm{C}\right)$ selama 10 menit. Supernatan diambil dan diendapkan dengan tiga kali volume etanol, lalu endapan dikeringkan dengan freeze dryer.

Metode ekstraksi dengan pelarut air dilakukan dengan cara merendam sampel dalam akuabides (1:20) $(\mathrm{b} / \mathrm{v})$, diaduk dengan magnetic stirer pada suhu $85^{\circ} \mathrm{C}$ selama 4 jam, lalu disaring. Filtrat ditambahkan dengan larutan $\mathrm{CaCl}_{2} 2 \%(1: 10)(\mathrm{v} / \mathrm{v})$, diaduk selama 30 menit pada suhu ruang, disentrifusi $(11664 \times g$ $\left.5^{\circ} \mathrm{C}\right)$ selama 15 menit. Filtrat kemudian diendapkan dengan dua kali volume etanol dan dibiarkan semalaman. Endapan yang diperoleh kemudian dikeringbekukan dengan freeze dryer.

Kedua ekstrak fukoidan kasar tersebut kemudian dihitung rendemennya, dan dianalisis total padatan, total karbohidrat, total sulfat, aktivitas penghambatan $\alpha$-amilase and $\alpha$-glukosidase, dan spektra serapan IRnya. Rendemen dihitung sebagai persen dari berat tepung rumput laut terhadap berat sampel.

\section{Fraksinasi fukoidan dengan ultrafiltrasi}

Fraksinasi ultrafiltrasi dilakukan untuk mendapatkan tiga fraksi fukoidan dengan berat molekul $<10 \mathrm{kDa}, 10-30 \mathrm{kDa}$ dan $>30 \mathrm{kDa}$ dengan menggunakan membran ultrafiltrasi 10 dan $30 \mathrm{kDa}$. Sebanyak $50 \mathrm{mg}$ ekstrak fukoidan dilarutkan dengan $3,0 \mathrm{~mL}$ akuabides, lalu disentrifusi dan filtratnya dimasukkan ke dalam tabung ultrafiltrasi 30 $\mathrm{kDa}$, dan disentrifusi $\left(11664 \times \mathrm{g} 5^{\circ} \mathrm{C}\right)$ selama 30 menit. Filtrat kemudian dikumpulkan dan dimasukkan ke dalam tabung ultrafiltrasi $10 \mathrm{kDa}$, lalu disentrifusi kembali $(11664 \times \mathrm{g}$ $5^{\circ} \mathrm{C}, 60$ menit). Tiga fraksi yang diperoleh (berat molekul $<10 \mathrm{kDa}, 10-30 \mathrm{kDa}$ dan $>30 \mathrm{kDa}$ ) dikeringkan dengan freeze dryer. Masing-masing fraksi dilarutkan dalam 3,0 $\mathrm{mL}$ akuabides dengan volume yang sama dengan sampel sebelum ultrafiltrasi agar dapat dibandingkan aktivitasnya. Ultrafiltrasi dilakukan dua kali, dan fraksi yang mirip dikumpulkan, sehingga diperoleh 6,0 mL hasil ultrafiltrasi. Ketiga fraksi kemudian dianalisis total padatan, total karbohidrat, sulfat dan aktivitas penghambatan terhadap $\alpha$-amilase dan a-glukosidase secara in vitro.

\section{Fraksinasi dengan kromatograsi filtrasi gel}

Fraksinasi hasil ultrafiltrasi dari ekstrak fukoidan dilakukan dengan kromatografi filtrasi gel sesuai hasil aktivitas penghambatan tertinggi pada pengujian sebelumnya (fase diam: kolom Sephadex G-75 berukuran 1,5 $\mathrm{cm}$ (diameter) x $60 \mathrm{~cm}$ (tinggi); fase gerak: aquabides dengan laju alir eluen $1 \mathrm{~mL} /$ menit pada suhu ruang dan tekanan atmosfir $1 \mathrm{~Pa}$ ). Fraksi fukoidan yang diaplikasikan dipilih dari fraksi terbesar dari hasil fraksinasi dengan ultrafitrasi. Sampel $(1,0 \mathrm{~mL})$ dimasukkan ke dalam kromatografi filtrasi gel. Eluat yang terkumpul (60 tabung, masing-masing 5,0 $\mathrm{mL}$ ) ditampung dan diukur absorbansinya dengan spektrofotomer UV-Vis pada panjang gelombang $490 \mathrm{~nm}$ (Sinurat 2011). Puncak yang dihasilkan dari beberapa tabung 
dikumpulkan menjadi satu fraksi sampai diperoleh absorbansi tetap. Masing-masing fraksi dikeringkan dengan freeze dryer. Fraksi kering beku dari 6 ulangan kromatografi dilarutkan dalam $6.0 \mathrm{~mL}$ akuabides, dianalisis total padatan, total karbohidrat, total sulfat, berat molekul dan aktivitas penghambatan a-amilase dan $\alpha$-glukosidase secara in vitro.

\section{Analisis total padatan}

Sampel ekstrak fukoidan dan fraksinya dianalisis total padatannya dengan metode gravimetri. Sampel ditimbang dan dikeringkan dengan menggunakan pengering beku hingga kering $( \pm 24$ jam). Sampel yang sudah dikeringkan kemudian ditimbang beratnya. Total padatan dinyatakan sebagai persen dari berat padatan setelah dikeringkan terhadap berat sampel awal.

Analisis kadar sulfat (Kim et al. 2007)

Sampel ekstrak fukoidan $(0,1 \mathrm{~mL})$ dari larutan $50 \mathrm{mg}$ ekstrak $/ 3,0 \mathrm{~mL}$ akuabides ditambahkan asam trikloroasetat (TCA) $4 \%$ sebanyak 1,0 $\mathrm{mL}$ lalu dipanaskan pada suhu $100^{\circ} \mathrm{C}$ selama 4 jam dalam waterbath. Setelah didinginkan pada suhu ruang, diambil $0,2 \mathrm{~mL}$ sampel dan ditambahkan larutan gelatin- $\mathrm{BaCl}_{2} 0,2 \mathrm{~mL}$ dan TCA $0,35 \mathrm{~mL}$, lalu distirer selama 60 detik. Larutan sampel diukur dengan spektrofotometer UV-vis pada panjang gelombang $420 \mathrm{~nm}$. Standar yang digunakan adalah $\mathrm{Na}_{2} \mathrm{SO}_{4}$ dengan konsentrasi 0,5, 1, 5, 10 dan 15 ppm (Kim et al. 2007).

\section{Analisis karbohidrat}

Sampel ekstrak fukoidan dan hasil fraksinasinya dianalisis kadar karbohidratnya dengan metode fenol-sulfat. Sampel $(50 \mu \mathrm{L})$ ditambahkan $30 \mu \mathrm{L}$ fenol $5 \%$ dan $150 \mu \mathrm{L}$ asam sulfat pekat. Larutan diaduk dan warna yang terbentuk diukur absorbansinya dengan ELISA reader pada panjang gelombang 490 $\mathrm{nm}$. Standar yang digunakan adalah L-fukosa dengan konsentrasi 0,$00 ; 0,025 ; 0,05 ; 0,075$; 0,10 dan 0,12 (\%). Blanko menggunakan larutan seperti pada sampel tanpa penambahan sampel. Kadar karbohidrat dinyatakan dalam persen basis basah (Dubois et al. 1956).

\section{Analisis Gugus Fungsi dengan FTIR}

Sampel ekstrak fukoidan ditempatkan dalam tempat sampel, kemudian ditambahkan $\mathrm{KBr}$ untuk membentuk lapisan cakram $\mathrm{KBr}$. Lapisan kemudian diukur pada bilangan gelombang 400-4000 $\mathrm{cm}^{-1}$. Sebelum pengukuran, cakram $\mathrm{KBr}$ dibersihkan dan dibilas dengan $\mathrm{n}$-heksana murni dan dikeringkan dengan tissue untuk memastikan tidak ada residu yang tersisa pada tempat cakram $\mathrm{KBr}$.

\section{Analisis aktivitas penghambatan $\alpha$-amilase}

Analisis aktivitas penghambatan terhadap $\alpha$-amilase dari sampel ekstrak fukoidan atau fraksinya mengacu pada metode Thalapaneni et al. (2008) dengan modifikasi. Sebanyak $125 \mu \mathrm{L}$ larutan sampel dicampurkan dengan $125 \mu \mathrm{L}$ larutan $\alpha$-amilase dari porcine pancreatic ( $1 \mathrm{unit} / \mathrm{mL}$ ), kemudian diinkubasi selama 10 menit pada $37^{\circ} \mathrm{C}$ dengan penangas air. Kemudian ditambahkan sebanyak 125 $\mu \mathrm{L}$ larutan pati kentang $1 \% \mathrm{~b} / \mathrm{v}$, kemudian diinkubasi kembali selama 10 menit pada suhu $37^{\circ} \mathrm{C}$ dengan penangas air. Reaksi dihentikan dengan menambahkan $500 \mu \mathrm{L}$ pereaksi DNS 0,096 M dan diinkubasi selama 5 menit dalam air mendidih dengan penangas air. Air demineral sebanyak $5000 \mu \mathrm{L}$ ditambahkan, lalu dilakukan pengukuran absorbansi pada $540 \mathrm{~nm}$ dengan spektrofotometer UVVis. Kontrol blanko (kontrol A) disiapkan dengan mengganti ekstrak fukoidan dengan $125 \mu \mathrm{L}$ bufer dan blanko sampel (kontrol B) disiapkan menggunakan ekstrak tanpa adanya penambahan enzim. Blanko disiapkan dengan cara yang sama tanpa penambahan sampel dan enzim. Acarbose $(1 \mathrm{mg} / \mathrm{mL})$ digunakan sebagai kontrol positif dengan cara melarutkannya dalam $100 \mathrm{~mL} \mathrm{HCl} 2$ $\mathrm{N}$. Efek penghambatan aktivitas $\alpha$-amilase dinyatakan dalam persen penghambatan yang dihitung dengan rumus berikut $(\mathrm{A} 1=$ Absorbansi kontrol A - Absorbansi blanko; A2 = Absorbansi sampel - Absorbansi kontrol B):

$$
\% \text { penghambatan }=\frac{\mathrm{A} 1-\mathrm{A} 2}{\mathrm{~A} 1} \times 100 \%
$$




\section{Analisis aktivitas penghambatan $\alpha$-glukosidase}

Analisis aktivitas penghambatan terhadap $\alpha$-glukosidase dari sampel ekstrak fukoidan atau fraksinya mengacu pada metode Sancheti et al. (2009). Sampel (10 $\mu \mathrm{L})$ ditambahkan dengan $50 \mu \mathrm{L}$ larutan bufer kalium fosfat $\mathrm{pH} 7,0 ; 25 \mu \mathrm{L}$ substrat (PNPG $10 \mathrm{mM}$ ) dan $25 \mu \mathrm{L}$ a-glukosidase $(0,04 \mathrm{unit} / \mathrm{mL})$. Larutan campuran diinkubasi selama 30 menit pada suhu $37^{\circ} \mathrm{C}$, kemudian ditambahkan larutan $\mathrm{Na}_{2} \mathrm{CO}_{3}$ 0,2 $\mathrm{M}$ sebanyak $100 \mu \mathrm{L}$. Absorbansi diukur dengan ELISA reader pada panjang gelombang $405 \mathrm{~nm}$. Kontrol blanko (kontrol A) disiapkan dengan mengganti ekstrak fukoidan dengan $125 \mu \mathrm{L}$ bufer dan blanko sampel (kontrol B) disiapkan dengan menggunakan ekstrak tanpa adanya penambahan enzim. Blanko disiapkan dengan cara yang sama tanpa penambahan sampel dan enzim. Efek penghambatan aktivitas a-glukosidase dinyatakan dalam persen penghambatan yang dihitung dengan rumus berikut:

$$
\% \text { penghambatan }=\frac{\mathrm{A} 1-\mathrm{A} 2}{\mathrm{~A} 1} \times 100 \%
$$

$\mathrm{A} 1$ = absorbansi kontrol A - absorbansi blanko; A2 = absorbansi sampel - absorbansi kontrol B

\section{Analisis berat molekul}

Analisis berat molekul fukoidan dilakukan menggunakan kromatografi filtrasi gel Sephadex G-75 dan standar dekstran dengan berat molekul $70 \mathrm{kDa}$. Masing-masing fraksi hasil fraksinasi kromatografi filtrasi gel diaplikasikan sebanyak $1,0 \mathrm{~mL}$ dengan konsentrasi masing-masing total padatan (SF-I $=4,33 \mathrm{mg} / \mathrm{mL}$; SF-II $=1,38 \mathrm{mg} / \mathrm{mL}$; TF$\mathrm{I}=3,50 \mathrm{mg} / \mathrm{mL}$ dan TF-II $=3,08 \mathrm{mg} / \mathrm{mL}$ ) dan dibandingkan waktu elusinya dengan standar dekstran berat molekul $70 \mathrm{kDa}$ dengan konsentrasi $10 \mathrm{mg} / \mathrm{mL}$. Eluen yang digunakan adalah akuabides dengan laju alir eluen $1 \mathrm{~mL} /$ menit.

\section{Analisis Data}

Data hasil ekstraksi, fraksinasi ultrafiltrasi dan fraksinasi kromatografi filtrasi gel dianalisis dengan uji analisis varian univariat atau one-way ANOVA (IBM SPSS 23, USA) pada taraf signifikansi 5\%. Apabila terdapat perbedaan, maka data diolah lebih lanjut menggunakan uji Duncan. Data yang ditampilkan berupa rata-rata \pm standar deviasi dari dua kali ulangan percobaan.

\section{HASIL DAN PEMBAHASAN Karakterisik Tepung Rumput Laut}

Rumput laut cokelat yang telah dibersihkan dan dikeringkan menghasilkan rendemen tepung rumput laut sebanyak $13,35 \%$ untuk T. conoides yang lebih besar dibandingkan tepung S. polycystum (7,95\%). Hal ini karena talus $T$. conoides berbentuk batang yang lebih besar dan keras, sedangkan tallus S. polycystum sebagian besar berupa lembaran daun (Manteu et al. 2018; Nurjanah et al. 2019). Komposisi kimia kedua tepung rumput laut cokelat tersebut berbeda nyata $(\mathrm{p}<0,05)$, kecuali kadar lemak (Table 1). Rumput laut mengandung kadar abu, kadar karbohidrat, protein dan serat makanan yang tinggi. Tepung S. polycystum mengandung protein dan karbohidrat yang lebih tinggi dibandingkan T. conoides, namun mengandung abu yang lebih rendah. Perbedaan jenis, lokasi tumbuh dan umur panen dari rumput laut dapat mempengaruhi komposisi kimia rumput laut (Matanjun et al. 2009; Tapotubun 2018).

Table 1 Chemical composition of brown seaweed flour

\begin{tabular}{ccc}
\hline Component $(\% \mathrm{wb})$ & S. polycystum & T. conoides \\
\hline Water & $11.27 \pm 0.02^{\mathrm{b}}$ & $9.69 \pm 0.05^{\mathrm{a}}$ \\
Ash & $14.07 \pm 0.06^{\mathrm{a}}$ & $31.82 \pm 0.16^{\mathrm{b}}$ \\
Protein & $36.82 \pm 0.61^{\mathrm{b}}$ & $26.01 \pm 0.13^{\mathrm{a}}$ \\
Lipid & $1.16 \pm 0.11^{\mathrm{a}}$ & $1.02 \pm 0.01^{\mathrm{a}}$ \\
Carbohydrate (by difference) & $28.60 \pm 0.67^{\mathrm{b}}$ & $22.64 \pm 0.13^{\mathrm{a}}$ \\
\hline
\end{tabular}

Note: number at the same row for each parameter followed by different letter showed significantly different $(\mathrm{p}<0.05)$ 


\section{Karakteristik fukoidan kasar}

Ekstrak fukoidan dari kedua tepung rumput laut dengan metode ekstraksi air lebih tinggi dibandingkan metode ekstraksi asam (Table 2). Ekstrak fukoidan dari S. polycystum dengan metode air lebih tinggi dibandingkan ekstrak dari metode asam. Junaidi (2013), Sinurat dan Kusumawati (2017) melaporkan hal yang sama bahwa metode ekstraksi air menghasilkan rendemen ekstrak fukoidan yang lebih tinggi dibandingkan metode asam. Adanya proses pemanasan dalam ekstraksi air dapat menghancurkan dinding sel sehingga dapat mengekstrak fukoidan lebih banyak. Ekstrak fukoidan dari ekstraksi air juga memiliki warna yang lebih cokelat dibandingkan esktraksi asam. Penelitian lain juga menunjukkan rendemen ekstrak fukoidan dengan metode asam yang relatif sama, misalnya $S$. crassifolium $(1,46 \% \mathrm{bk})$ (Sinurat 2011), dan K. crassifolia (5,1\%bk), S. horneri (4,5\%bk), C. okamuranus (4,0\%bk), dan N. decipiens (1,2\%bk) (Ajisaka et al. 2016); S. duplicatum (2,09\%bk) dan T. decurrens (1,45\%bk) (Hardoko et al. 2014).

Table 2 menunjukkan kemampuan penghambatan dari ekstrak fukoidan $S$. polycystum dan T. conoides terhadap aktivitas $\alpha$-amilase dan $\alpha$-glukosidase pada konsentrasi ekstrak 0,025 mg/mL. Ekstrak fukoidan dari S. polycystum, baik dengan ekstraksi asam maupun air, menunjukkan kemampuan menghambat aktivitas $\alpha$-amilase dan $\alpha$-glukosidase, sedangkan untuk T. conoides, hanya ekstrak fukoidan dari ekstraksi air yang menunjukkan kemampuan penghambatan untuk kedua enzim tersebut. Persen penghambatan terhadap $\alpha$-glukosidase dari penelitian ini lebih kecil dari hasil Hardoko et al. (2014) namun lebih tinggi dari hasil Yin (2013). Perbedaan aktivitas penghambatan ini dapat disebabkan oleh perbedaan lokasi, musim, jenis, struktur dan berat molekul fukoidan yang diekstrak.

Ekstrak fukoidan dari S. polycystum memberikan aktivitas penghambatan yang lebih tinggi dibandingkan dari $T$. conoides. Table 2 menunjukkan bahwa ekstrak fukoidan dari S. polycystum dari metode asam memiliki aktivitas penghambatan yang lebih tinggi dibandingkan ekstraksi air, sedangkan untuk $T$. conoides menunjukkan aktivitas yang lebih tinggi untuk metode ekstraksi air. Hasil ekstraksi asam diduga menyebabkan terjadinya hidrolisis dibandingkan dengan ekstraksi air sehingga menghasilkan fukoidan dengan berat molekul rendah (Sinurat dan Maulida 2018; Liu et al. 2016).

Ekstrak fukoidan dari S. polycystum (metode esktraksi asam) dan T. conoides (metode ekstraksi air) mengandung karbohidrat dengan gugus sulfat yang menunjukkan keberadaan fukoidan dalam ekstrak (Table 3). Hasil ini dikonfirmasi oleh

Table 2 Yield and inhibition activities to $\alpha$-amylase and $\alpha$-glucosidase crude fucoidan extract

\begin{tabular}{lcccccc}
\hline \multirow{2}{*}{$\begin{array}{c}\text { Fucoidan } \\
\text { extract }\end{array}$} & \multicolumn{2}{c}{ Yield (\%) } & \multicolumn{4}{c}{ Inhibition activity (\%) } \\
\cline { 2 - 7 } & Acid & Water & Acid & Water & Acid & Water \\
\cline { 2 - 6 } & $4.48+0.9^{\mathrm{a}}$ & $8.80+0.86^{\mathrm{b}}$ & $30.57 \pm 0.64^{\mathrm{b}}$ & $6.30 \pm 0.07^{\mathrm{a}}$ & $9.60 \pm 0.74^{\mathrm{a}}$ & $0.43 \pm 0.01^{\mathrm{a}}$ \\
S. polycystum & $3.20+0.50^{\mathrm{a}}$ & $7.59+0.60^{\mathrm{b}}$ & $5.26 \pm 2.21^{\mathrm{a}}$ & $9.94 \pm 1.16^{\mathrm{b}}$ & n.d. & $9.20 \pm 1.82$ \\
\hline T. conoides & & &
\end{tabular}

Note:number at the same row for each parameter followed by different letter showed significantly different $(\mathrm{p}<0.05)$; n.d.: not detected

Table 3 Total solid, carbohydrate and sulphate contents of fucoidan extract from S. polycystum and T. conoides

\begin{tabular}{lrr}
\multirow{2}{*}{\multicolumn{1}{c}{ Component }} & \multicolumn{2}{c}{ Fucoidan extract ${ }^{1}$} \\
\cline { 2 - 3 } & S. polycystum & T. conoides \\
\hline Total solid (\%b/v) & $16.70 \pm 0.04^{\mathrm{a}}$ & $16.73 \pm 0.00^{\mathrm{a}}$ \\
Total carbohydrate (\%b/b) & $14.74 \pm 3.28^{\mathrm{a}}$ & $18.19 \pm 3.21^{\mathrm{a}}$ \\
Total sulphate $(\% \mathrm{~b} / \mathrm{b})$ & $4.81 \pm 0.86^{\mathrm{a}}$ & $6.64 \pm 1.82^{\mathrm{a}}$ \\
\hline
\end{tabular}

Note: ${ }^{1}$ Concentration extract for $50 \mathrm{mg}$ (dry matter) in $3.0 \mathrm{~mL}$ aquabidest; number at the same row for each parameter followed by different letter letter showed significantly different $(\mathrm{p}<0.05)$ 


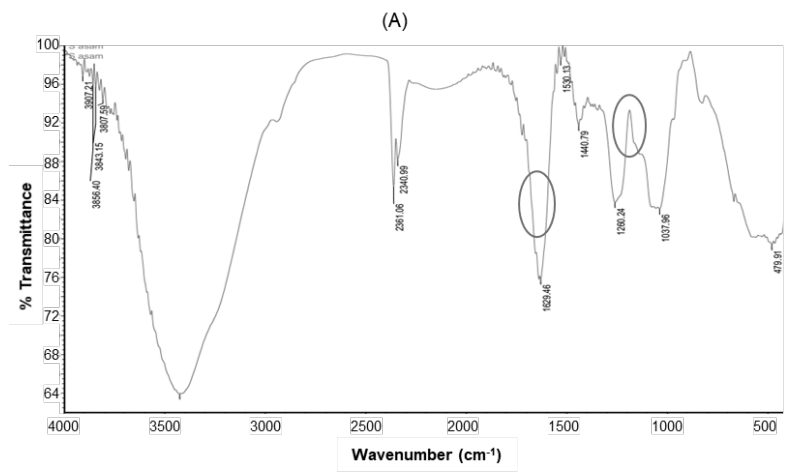

(B)

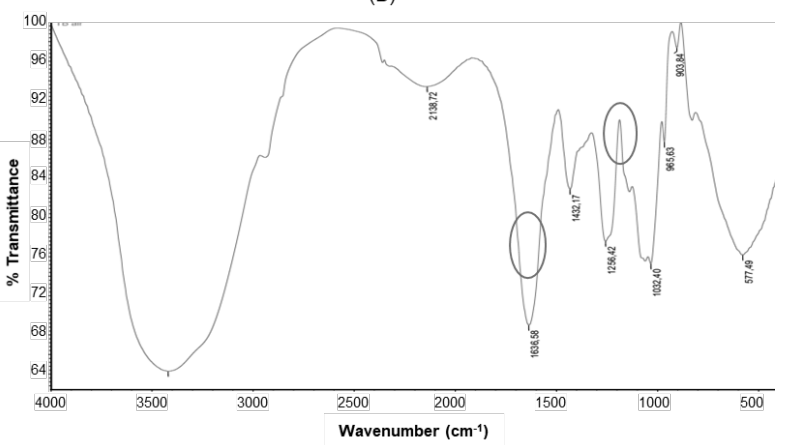

Figure 1 The IR spectrum of fucoidan extract from S. polycystum (acid extraction) (A) and T. conoides (water extraction) (B). Peak with a circle indicates the position of sulphate group

Table 4 IR spectra of fucoidan extract from S. polycystum (acid extraction) and T. conoides (water extraction)

\begin{tabular}{lcl}
\cline { 2 - 3 } Fucoidan extract & Wave number $\left(\mathrm{cm}^{-1}\right)$ & Peak shape \\
\hline $3600-3400$ & wide, strong \\
$2100-2300$ & narrow, medium \\
S. polycystum & 1600 & narrow, medium \\
$1260-1250$ & narrow, weak \\
1000 & narrow, weak \\
$850-820$ & narrow, weak \\
$3600-3400$ & wide, strong \\
1600 & narrow, strong \\
T. conoides & $1260-1250$ & narrow, weak \\
1000 & narrow, medium \\
$850-820$ & narrow, weak \\
\hline
\end{tabular}

profil spektroskopi FTIR yang menunjukkan adanya gugus sulfat dan hidroksil (Figure $1 A$ dan $1 B$ ) dan daerah serapan dari spektra IR yang teridentifikasi disajikan pada Table 4. Gugus sulfat teridentifikasi pada daerah serapan $1260-1250 \mathrm{~cm}^{-1}$ dan $850-820 \mathrm{~cm}^{-1}$, sedangkan gugus hidroksil pada daerah serapan 3600 $3400 \mathrm{~cm}^{-1}$. Figure $1 A$ dan $1 B$ menunjukkan puncak serapan yang kuat dan lebar pada daerah $3600-3400 \mathrm{~cm}^{-1}$, baik pada spektra IR $S$. polycystum maupun T. conoides yang secara jelas menunjukkan adanya gugus fungsional hidroksil yang berasal dari monomer gula penyusun struktur fukoidan. Intensitas serapan pada daerah $1260-1250 \mathrm{~cm}^{-1}$ dan 850-820 $\mathrm{cm}^{-1}$ berbeda antara spektra IR $S$. polycystum dan T. conoides yang menunjukkan bahwa molekul fukoidan dari kedua esktrak ini kemungkinan memiliki panjang polimer atau berat molekul yang berbeda. 


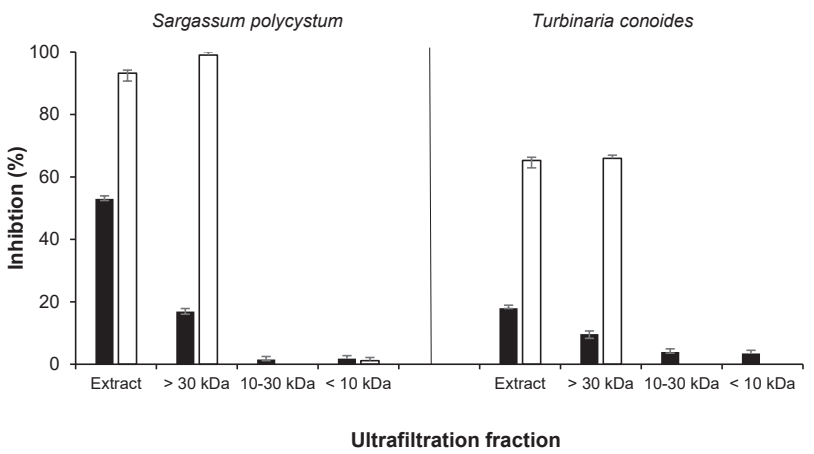

Figure 2 Inhibition activity to $a$-amylase dan a-glucosidase from of fucoidan extract (50 mg solid/3.0 mL) and their ultrafiltration $(10$ and $30 \mathrm{kDa}$ ). Fraction of $10-30 \mathrm{kDa}$ and $<10 \mathrm{kDa}$ from $S$ polycycstum and $T$. conoides did not exhibit inhibition activity to $\alpha$-glucosidase; $\mathbf{\square}$-amylase; $\square$ a-glucosidase
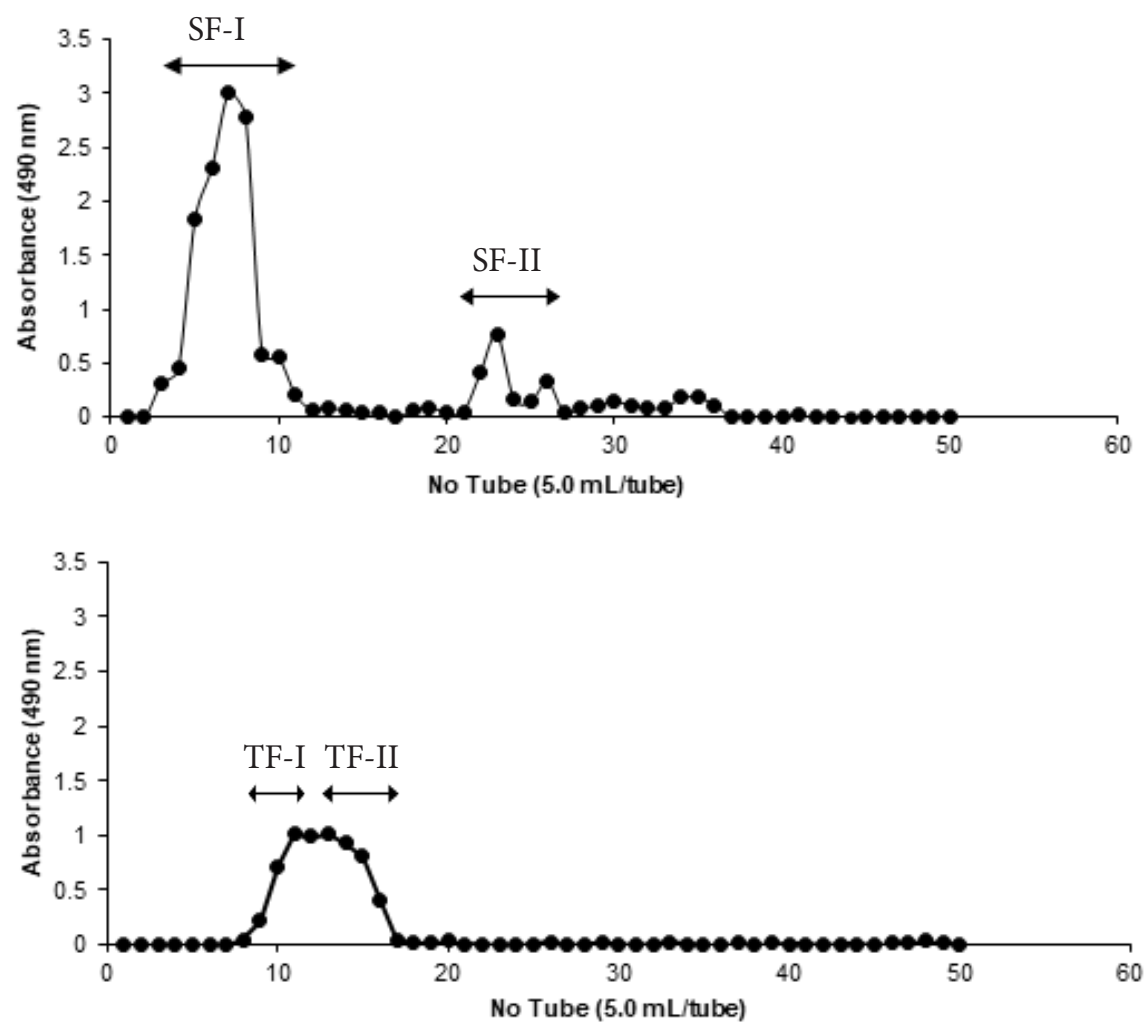

Figure 3 Absorbance readings at $490 \mathrm{~nm}$ from $>30 \mathrm{kDa}$ fraction of Sephadex G-75 gel filtration chromatogratography (A) Sargassum polycystum; (B) T. conoides.

\section{Karakteristik Fraksi Fukoidan Hasil Ultrafiltrasi}

Hasil fraksinasi ekstrak fukoidan menunjukkan kandungan total padatan, kadar karbohidrat dan kadar total sulfat yang berbeda pada fraksi $>10 \mathrm{kDa}, 10-20 \mathrm{kDa}$ dan $>30 \mathrm{kDa}$ (Table 5). Kedua ekstrak fukoidan rumput laut pada fraksi $>30 \mathrm{kDa}$ memiliki total padatan, kadar total karbohidrat dan kadar total sulfat yang paling tinggi, diikuti fraksi $<10 \mathrm{kDa}$ dan $10-30 \mathrm{kDa}$. Dari hasil ini diketahui bahwa fraksi fukoidan dengan berat molekul yang lebih besar menunjukkan gugus sufat yang lebih banyak. Hal ini menunjukkan komponen fukoidan dalam fraksi $>30 \mathrm{kDa}$ yang tentunya memiliki berat molekul $>30$ $\mathrm{kDa}$ memiliki lebih banyak gugus sulfat yang dapat menentukan bioaktivitasnya. Hal ini dikonfirmasi dari hasil uji aktivitas penghambatan dari masing-masing fraksi tersebut yang menggambarkan aktivitas penghambatan ekstrak asalnya (Figure 
Table 5 Total solid, carbohydrate and sulphate contents of ultrafiltration and G-75 gel filtration chromatography fractions of fucoidan from S. polycystum (acid extraction) and T. conoides (water extraction) maximum tolerable concentration of heavy metal content in fish meat according to SNI 7387 (2009) and JEFCA (2004)

\begin{tabular}{lccc}
\hline \multicolumn{1}{c}{ Fucoidan fraction } & $\begin{array}{c}\text { Total solid } \\
(\% \mathrm{w} / \mathrm{v})\end{array}$ & $\begin{array}{c}\text { Total carbohydrate } \\
(\% \mathrm{w} / \mathrm{w})\end{array}$ & $\begin{array}{c}\text { Total sulphate } \\
(\% \mathrm{w} / \mathrm{v})\end{array}$ \\
\hline $\begin{array}{l}\text { Ultrafiltration fraction } \\
\text { S. polycystum }\end{array}$ & & & \\
$>30 \mathrm{kDa}$ & $7.51 \pm 0.16^{\mathrm{b}}$ & $19.81 \pm 2.38^{\mathrm{b}}$ & $11.68 \pm 3.82^{\mathrm{a}}$ \\
$10-30 \mathrm{kDa}$ & $0.89 \pm 0.02^{\mathrm{e}}$ & $26.04 \pm 4.83^{\mathrm{a}}$ & $3.16 \pm 2.73^{\mathrm{b}}$ \\
$<10 \mathrm{kDa}$ & $5.44 \pm 0.05^{\mathrm{c}}$ & $7.41 \pm 1.06^{\mathrm{d}}$ & $1.05 \pm 0.15^{\mathrm{c}}$ \\
T. conoides & & & $8.39 \pm 0.79^{\mathrm{a}}$ \\
$>30 \mathrm{kDa}$ & $9.12 \pm 0.35^{\mathrm{a}}$ & $16.59 \pm 4.31^{\mathrm{b}}$ & $3.90 \pm 1.15^{\mathrm{b}}$ \\
$10-30 \mathrm{kDa}$ & $0.35 \pm 0.07^{\mathrm{f}}$ & $7.55 \pm 0.13^{\mathrm{d}}$ & $3.52 \pm 0.08^{\mathrm{b}}$ \\
$<10 \mathrm{kDa}$ & $2.45 \pm 0.03^{\mathrm{d}}$ & $10.33 \pm 2.38^{\mathrm{c}}$ & \\
Gel filtration chromatography fraction & & $11.03 \pm 3.62^{\mathrm{a}}$ \\
S. polycystum & & & $13.77 \pm 14.26^{\mathrm{a}}$ \\
SF-I & $4.33 \_1.23^{\mathrm{b}}$ & $25.91 \pm 1.74^{\mathrm{b}}$ & \\
SF-II & $1.38+0.80^{\mathrm{a}}$ & $11.08 \pm 2.85^{\mathrm{a}}$ & $11.46 \pm 6.10^{\mathrm{a}}$ \\
T. conoides & & & $15.87 \pm 3.92^{\mathrm{a}}$ \\
TF-I & $3.50+1.10^{\mathrm{b}}$ & $26.53 \pm 2.00^{\mathrm{a}}$ & \\
TF-II & $3.08+0.75^{\mathrm{a}}$ & $26.33 \pm 0.90^{\mathrm{a}}$ & \\
\hline
\end{tabular}

${ }^{1}$ Total solid obtained from gel filtration chromatography was $6.0 \mathrm{~mL}$ from $>30 \mathrm{kDa}$ fraction

Number at the same column for each parameter followed by different letter showed significantly different $(\mathrm{p}<0.05)$

2). Fraksi $>30 \mathrm{kDa}$ dari S. polycystum dan T. conoides memiliki aktivitas penghambatan terhadap $\alpha$-amilase dan $\alpha$-glukosidase yang paling tinggi dibandingkan dua fraksi lainnya, meskipun aktivitasnya masih lebih rendah dibandingkan acarbose $(98,11 \%$ pada konsentrasi $1 \mathrm{mg} / \mathrm{mL}$ ).

Fraksi $>30 \mathrm{kDa}$ dari $S$. polycystum dan T. conoides memiliki kemampuan menghambat aktivitas a-glukosidase yang lebih besar daripada a-amilase. Fraksi 10$30 \mathrm{kDa}$ dan $<10 \mathrm{kDa}$ tidak menunjukkan aktivitas penghambatan a-glukosidase, baik dari S. polycystum maupun T. conoides. Hasil analisis ini menunjukkan fukoidan dengan berat molekul $>30 \mathrm{kDa}$ bertanggung jawab atas aktivitas penghambatan $\alpha$-amilase dan $\alpha$-glukosidase, baik untuk $S$. polycystum maupun T. conoides. Aktivitas ini kemungkinan berhubungan dengan gugus sulfat yang terdapat komponen fukoidan, karena kadar sulfat fraksi $>30 \mathrm{kDa}$ lebih besar daripada fraksi lainnya (Table 5). Aktivitas penghambatan fraksi fukoidan dari kedua rumput laut dalam penelitian ini terlihat relatif kuat terutama terhadap $\alpha$-glukosidase (lebih dari $60 \%$ ). Dengan demikian kedua fraksi ini memiliki potensi sebagai antidiabetes. Bagaimanapun, aktivitas ini dapat berbeda dari jenis rumput lainnya. Shan et al. (2016) melaporkan bahwa ekstrak fukoidan dari 10 jenis rumput laut tidak memiliki aktivitas penghambatan $\alpha$-amilase, namun menunjukkan aktivitas penghambatan yang besar pada $\alpha$-glukosidase. Kim et al. (2015) melaporkan bahwa fukoidan dari A. nodosum mampu menghambat aktivitas $\alpha$-amilase dan $\alpha$-glukosidase, namun penghambatan $\alpha$-amilase membutuhkan konsentrasi fukoidan yang lebih tinggi daripada untuk menghambat $\alpha$-glukosidase.

\section{Karakteristik Fraksi Kromatografi Filtrasi Gel}

Fraksi $>30 \mathrm{kDa}$ dari S. polycystum dan T. conoides selanjutnya difraksinasi lebih lanjut menggunakan kromatografi filtrasi gel Sephadex G-75 untuk memperoleh fraksi 


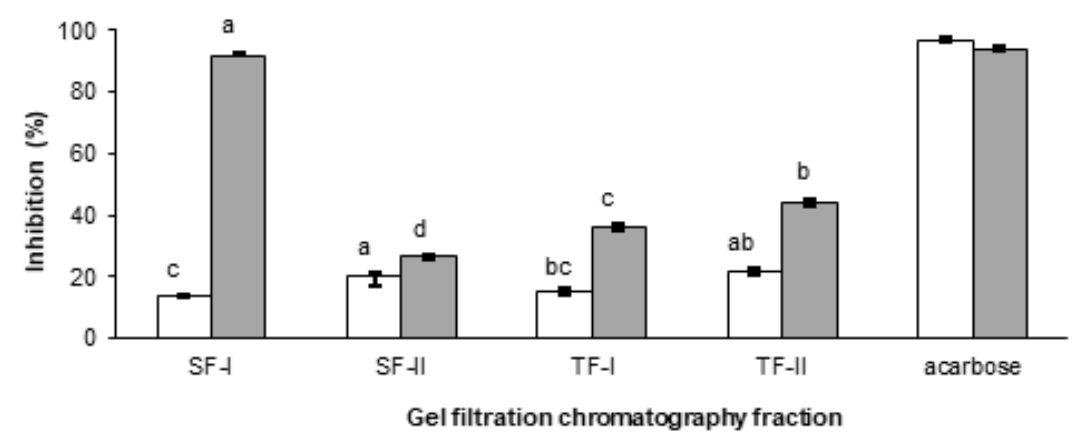

Figure 4 Inhibition activity of $\alpha$-amylase and $\alpha$-glucosidase from $>30 \mathrm{kDa}$ fraction of Sephadex G-75 gel gel filtration crhomatogratography. Fraction is expressed as dry weight diluted in $3 \mathrm{~mL}$ of aquabidest. For positive control, the inhibition for $\alpha$-amylase was at $0.5 \mathrm{mg} / \mathrm{mL}$ acarbose and for a-glucosidase $0.01 \mathrm{mg} / \mathrm{mL}$ acarbose; $\mathbf{a}$-amylase; $\square$ a-glucosidase; number for each parameter followed by different letter showed significantly different $(\mathrm{p}<0.05)$

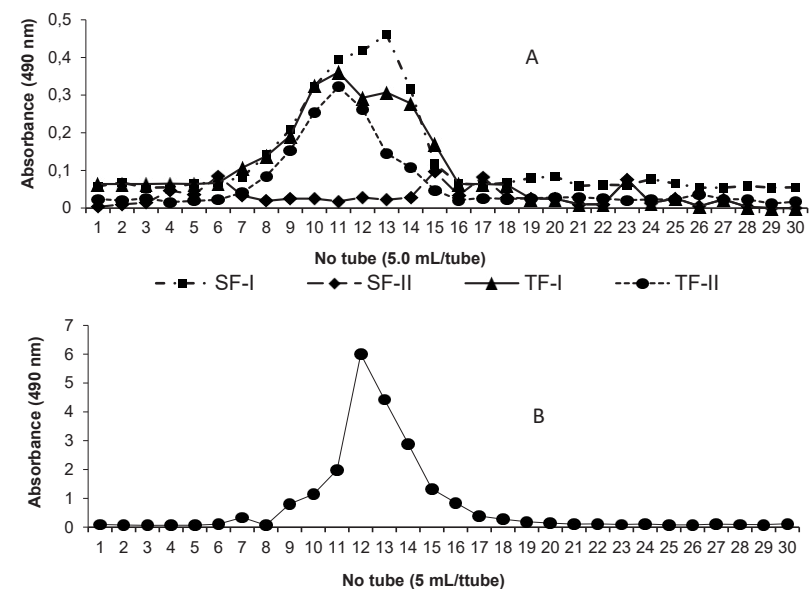

Figure 5 Absorbance readings at $490 \mathrm{~nm}$ from Sephadex G-75 gel fitration chromatography: (A) Active component fraction (>30 kDa); (b) dextran standard with $70 \mathrm{kDa}$

fukoidan yang lebih aktif. Kromatografi filtrasi gel memisahkan komponen berdasarkan ukuran molekulnya. Sampel yang dianalisis untuk masing-masing fraksi adalah $1,0 \mathrm{~mL}$ dengan konsentrasi padatan (dari freeze dryer) $7,53 \mathrm{mg} / \mathrm{mL}$ untuk S. polycystum dan 9,13 $\mathrm{mg} / \mathrm{mL}$ untuk $T$. conoides. Hasil fraksinasi kromatografi filtrasi gel memberikan dua fraksi, yaitu fraksi FI dan FII, fraksi FI memiliki berat molekul yang lebih besar daripada FII, sesuai dengan prinsip kromatografi filtrasi gel.

Kromatogram pada Figure $3 A$ dan $3 B$ menunjukkan puncak-puncak fraksi $>30$ $\mathrm{kDa}$ untuk $S$. polycystum dan T. conoides. Puncak yang lebih awal merupakan puncak dari komponen yang lebih besar ukurannya. Kedua fraksi $>30 \mathrm{kDa}$ dari kedua jenis rumput laut masing-masing menghasilkan dua puncak SF-I dan SF-II untuk S. polycystum dan TF-I dan TF-II untuk T. conoides. Fraksi SF-I dari S. polycystum dari tabung (3-12) memiliki berat molekul lebih besar dari fraksi SF-II dari tabung (21-28) dengan jarak yang cukup terpisah antar fraksi. Puncak-puncak dari fraksi $>30 \mathrm{kDa}$ untuk $T$. conoides jaraknya berdekatan dengan fraksi TF-I pada tabung (8-12) dan fraksi TF-II pada tabung (13-18), yang menunjukkan berat molekul TF-I dan TF-II berdekatan.

Table 5 menunjukkan total padatan, total karbohidrat dan total sulfat. Untuk $S$. polycystum, total padatan dan karbohidrat untuk fraksi 1 (SF1) lebih besar daripada fraksi 2 (SFII), sedangkan untuk T. conoides fraksi 1 (TF-I) dan fraksi 2 (TF-II) total padatan dan total karbohidrat tidak berbeda nyata. Kedua fraksi, baik $S$. polycystum maupun $T$. conoides, mengandung total sulfat yang tidak berbeda nyata. Dengan demikian pada fraksi fukoidan dengan berat molekul $>30 \mathrm{kDa}$, yang mengandung polimer yang relatif panjang, gugus sulfat dapat sama 
jumlahnya antara komponen fukoidan yang berbeda ukuran molekulnya. Meskipun demikian bioaktivitasnya dapat berbeda. Hal ini dibuktikan dengan uji penghambatan terhadap enzim $\alpha$-amilase dan $\alpha$-glukosidase di bawah ini.

Hasil uji aktivitas penghambatan dari hasil fraksinasi dengan kromatograsi filtrasi terhadap $\alpha$-amilase dan $\alpha$-glukosidase disajikan pada Figure 4. Kedua fraksi menunjukkan aktivitas penghambatan yang lebih tinggi terhadap a-glukosidase, yang mengkonfirmasi dari hasil pengujian dari fraksinasi dengan ultrafiltrasi (Figure 2). Fraksi SF-I dari S. polycystum mempunyai aktivitas penghambatan yang lebih besar terhadap $\alpha$-glukosidase daripada SF-II, sedangkan dari T. conoides fraksi TF-II memberikan aktivitas penghambatan terhadap $\alpha$-glukosidase yang lebih besar daripada TF-I. Halinimenunjukkan bahwa komponen fukoidan dari S. polycystum yang memiliki aktivitas penghambatan $\alpha$-glukosidase lebih besar terutama adalah yang memiliki berat molekul lebih kecil, sedangkan untuk $T$. conoides adalah yang berat molekulnya lebih besar. Hal sebaliknya terjadi untuk aktivitas penghambatan untuk $\alpha$-amilase (Figure 4). Dengan demikian SF-I dan TF-II adalah fraksi fukoidan yang paling aktif. Keduanya memiliki total sulfat yang tidak berbeda nyata (Table 5) tetapi memiliki ukuran molekul berbeda sesuai hasil kromatografi filtrasi gel (Figure 3), yang dibuktikan pada pengujian berikutnya (Figure 5) dan penjelasan di bawah ini. Fraksi SF-I memiliki aktivitas penghambatan yang lebih tinggi daripada TF-II, hal ini membuktikan bahwa struktur fukoidan menentukan aktivitas penghambatan, selain jumlah gugus sulfatnya.

Analisis lebih lanjut dilakukan dengan kromatografi filtrasi gel yang sama untuk menentukan kisaran berat molekul masingmasing fraksi. Dalam analisis ini digunakan eluen akuabides dengan laju alir $1 \mathrm{~mL} /$ menit dan standar dekstran berat molekul $70 \mathrm{kDa}$, yang hasilnya disajikan pada Figure 5A-5B. Fraksi SF-I, TF-I dan TF-II masingmasing mempunyai dua puncak yang menggambarkan fraksi tersebut kemungkinan masih merupakan campuran dan memiliki dua komponen aktif yang memiliki aktivitas penghambatan terhadap $\alpha$-amilase dan $\alpha$-glukosidase. SF-I terdiri komponen fukoidan yang memiliki berat molekul $>70$ $\mathrm{kDa}$ dan $30-70 \mathrm{kDa}$, namun fraksi yang utama (puncak tertinggi) memiliki berat molekul 30-70 kDa. Dengan demikian, maka dapat diketahui komponen fukoidan yang dominan dari $S$. polycystum dalam fraksi aktif SF-I memiliki berat molekul 30-70 $\mathrm{kDa}$ (Figure 5). Hasil ini bersesuaian dengan (Junaidi 2013) yang menunjukkan komponen aktif dari fukoidan Sargassum sp memiliki berat molekul 46,43 $\mathrm{kDa}$ (ekstrak asam) dan $57,77 \mathrm{kDa}$ (ekstrak air). Kim et al. (2012) juga melaporkan bahwa fukoidan dengan berat molekul 5-30 kDa memiliki kemampuan antidiabetes dengan menghambat aktivitas $\alpha$-amilase dan $\alpha$-glukosidase.

TF-II yang merupakan fraksi aktif dari $T$. conoides terutama terdiri komponen dengan berat molekul $>70 \mathrm{kDa}$ (Figure 5). TF-I yang juga memiliki aktivitas (Figure 4) meskipun tidak setinggi TF-II terdiri dari komponen fukoidan dengan berat molekul $>70 \mathrm{kDa}$ dan 30-70 kDa (Figure 5), namun fraksi yang utama (puncak tertinggi) memiliki berat molekul $>70 \mathrm{kDa}$. Dengan demikian fraksi fukoidan aktif dari $T$. conoides adalah yang memiliki berat molekul $>70 \mathrm{kDa}$. Berat molekul komponen fukoidan dari rumput laut ini lebih besar daripada komponen dari rumput laut $S$. polycystum, dengan kadar sulfat rata-rata yang juga lebih tinggi (Table 5). Hal ini membuktikan ekstrak fukoidan yang diperoleh dari kedua rumput laut yang berbeda spesiesnya dalam penelitian ini memberikan gambaran komponen fukoidan aktif yang berbeda strukturnya karena berbeda berat molekul (Figure 5) serta rata-rata kadar sulfat (Table 5) dan intensitas spektra gugus sulfat (Figure 1). Selanjutnya penelitian yang lebih mendalam mengenai isolasi dan identifikasi senyawa fukoidan aktif dalam kedua fraksi SF-I dan TF-II diperlukan untuk memperoleh senyawa fukoidan yang dapat dimanfaatkan sebagai antidiabetes.

\section{KESIMPULAN}

Komponen fukoidan dapat diekstrak dari S. polycystum dan T. conoides masing- 
masing dengan metode ekstraksi asam dan air dan menunjukkan kemampuan penghambatan terhadap $\alpha$-amilase dan $\alpha$-glukosidase. Kemampuan dalam menghambat a-glukosidase lebih besar daripada terhadap $a$-amilase. Komponen aktif dari fraksi fukoidan kedua rumput laut tersebut, dari hasil ultrafiltrasi $(>30 \mathrm{kDa})$ dan kromatografi filtrasi gel, yang berperan dalam penghambatan aktivitas enzim $\alpha$-glukosidase dari S. polycystum terutama yang memiliki berat molekul 30-70 kDa dengan kadar sulfat rata-rata $11,03 \%$, sedangkan T. conoides dengan berat molekul $>70 \mathrm{kDa}$ dengan kandungan sulfat rata-rata $15,87 \%$. Aktivitas dari fraksi fukoidan yang berasal dari T. conoides lebih rendah dibandingkan dari S. polycystum. Hasil penelitian ini menunjukkan bahwa fraksi fukoidan dari S. polycystum (ekstrak asam) dan T. conoides (ekstrak air) memiliki potensi sebagai antidiabetes berdasarkan kemampuannya dalam menghambat aktivitas $\alpha$-amilase dan $\alpha$-glukosidase.

\section{DAFTAR PUSTAKA}

Ajisaka K, Yokoyama T, Matsuo K. 2016. Structural characterstics and antioxidant activities of fukoidan from five brown seaweeds. Journal of Applied Glycoscience. 63(2):31-37.

[AOAC] Association of Official Analytical Chemist. 2005. Official Method of Analysis of the Association of Official Analytical of Chemist. Virginia (US): The Association of Analytical Chemist, inc.

Chin YX, Lim PE, Maggs CA, Phang SM, Sharifuddin Y, Green BD. 2014. Antidiabetic potential of selected Malaysian seaweeds. Journal of Applied Phycology. 27: 2137-2148.

Descamps V, Colin S, Lahaye M, Jam M, Richard C, Pottin P, Barbeyron T, Yvin JC, Kloareg B. 2006. Isolation and culture of a marine bacterium degrading the sulfated fucans from marine brown algae. Marine Biotechnology. 8:27-39.

Dubois M, Gilles KA, Hamilton JK, Rebers PA, Smith F. 1956. Colorimetric method for determination of sugars and related substances. Analytical Chemistry. 28:350356.
Febriansah Y, Hardoko, Sasmito BB. 2013. Pengaruh pemberian crude fucoidan rumput laut Eucheuma cottonii terhadap kadar glukosa darah tikus putih wistar (Rattus novergicus). THPi Student Journal. 1(2): 71-80.

Hardoko, Siratantri T, Yogabuana M, Olivia S. 2014. An in vitro study of antidiabetic activity of Sargassum duplicatun and Turbinaria decurens seaweed. International Journal of Pharmaceutical Science Invention. 3(2):13-18.

Hjelland F, Andersen AH, Yang HS, inventor; FMC Corporation. 2012. Process for isolating fucoidan and laminarin from live, harvested seaweed. Patent United States US $0302742 \mathrm{~A} 1$.

January GG, Naidoo RK, Kirby-McCullough B, Bauer R. 2019. Assessing methodologies for fucoidan extraction from South African brown algae. Algal Research. 40: 1-8.

Junaidi L. 2013. Simple extraction and molecular weight characterization of fucoidan from Indonesian Sargassum sp. Biopropal Industri. 4(2): 49-57.

Kim WJ. 2007. Purification and anticoagulant activity of fucoidan from Korean Undaria pinnatifida sporophyll. Algae. 22(3):247252.

Kim KJ, Yoon KY, Lee BY. 2012. Fucoidan regulate blood glucose homeostasis in $\mathrm{C} 57 \mathrm{BL} / \mathrm{KSJ} \mathrm{m}+/+\mathrm{db}$ and C57BL/KSJ db/ $\mathrm{db}$ mice. Fitoterapia. 83:1105-1109.

Kim KT, Turgeon S, Rioux LE. 2015. Molecular weight and sulfate content modulate the inhibition of a-amylase by fucoidan relevant for type 2 diabetes management. Pharma Nutrition. 3(3):108-114.

Lee SH, Ko CI, Jee Y, Jeong Y, Kim M, Kim JS. 2013. Anti-inflammatory effect of fucoidan extracted from Ecklonia cava in zebrafish model. Carbohydrate Polymer. 92: 84-89.

Li B, Wei XY, Xu SY. 2006. Structural investigation of a fucoidan containing a fucose-free core from the brown seaweed Hizikia fusiforme. Carbohydrate Research. 341(9):1135-1146.

Lim SJ, Aida WMW, Maskat MY, Latip J, Badri KH, Hassan O, Yamin BM. 2016. 
Characterisation of fucoidan extracted from Malaysian Sargassum binderi. Food Chemistry. 209:267-273.

Lin HV, Tsou YC, Chen YT, Lu WJ, Hwang PA. 2017. Effects of low-molecular-weight fucoidan and high stability fucoxanthin on glucose homeostasis, lipid metabolism, and liver function in a mouse model of type II diabetes. Marine Drugs. 15(4):113.

Liu X, Liu B, Wei XL, Sun ZL and Wang CY. 2016. Extraction, fractionation, and chemical characterisation of fucoidans from the brown seaweed Sargassum pallidum. Czech Journal of Food Science. 34(5): 406-413.

Manteu SH, Nurjanah, Nurhayati T. 2018. Karakterisitik rumput laut cokelat (Sargassum policystum dan Padina minor) dari perairan Pohuwato Provinsi Gorontalo. Jurnal Pengolahan Hasil Perikanan Indonesia. 21(3): 396-405.

Marinval N, Saboural P, Haddad O, Maire M, Bassand K, Geinguenaud F, Djaker N, Akrout KB, Chapelle ML, Robert R, Oudar O, Guyot G, Morizot CL, Sutton A, Chauvierre C, Chaubet F, Charnaux N, Hlawaty H. 2016. Identification of a proangiogenic potential and cellular uptake mechanism of a LMW highly sulfated fraction of fucoidan from Ascophyllum nodosum. Marine Drugs. 14(10): 1-21.

Matanjun P, Mohamed S, Mustapha NM, Muhammad KH. 2009. Nutrien content of tropical edible seaweeds, Eucheuma cottonii, Caulerpa lentillifera and Sargassum polycystum. Journal of Applied Phycology. 21(1):75-80.

Nishino T, Kiyohara H, Yamada H, Nagumo T. 1991. An anticoagulant fucoidan from the brown seaweed Ecklonia kurome. Phytochemistry. 30(2):535-9.

Nurjanah, Fauziyah S, Abdullah A. 2019. Karakteristik bubur rumput laut Eucheuma cottonii dan Turbinaria conoides sebagai bahan baku masker peel off. Jurnal Pengolahan Hasil Perikanan Indonesia 22(2): 391-402.

Qu G, Liu X, Wang D, Yuan Y, Han L. 2014. Isolation and characterization of fucoidans from five brown algae and evaluation of their antioxidant activity.
Journal of Ocean University of China. 13: 851-856.

Rioux LE, Turgeon SL, Beaulieu M. 2009. Effect of season on the composition of bioactive polysaccharides from the brown seaweed Saccharina longicuris. Phytochemistry. 70:1069-1075.

Sancheti C, Sancheti S and Seo SY. 2009. Chaenomeles sinensis: a potent $\alpha$-and $\beta$-glucosidase inhibitor. American Journal Pharmacy and Toxicology. 4(1):8-11.

Shan X, Liu X, Hao J, Cai C, Fan F, Dun Y, Zhao X, Liu X, Li C, Yu G. 2016. In vitro and hypoglycemic effects of brown algal fucoidans. Journal Biological Macromolecules. 82:249-225.

Sinurat E, Peranginangin R, Saepudin E. 2011. Ekstraksi dan uji aktivitas fukoidan dari rumput laut cokelat (Sargassum crassifolium) sebagai antikoagulan. Jurnal Pascapanen dan Bioteknologi Kelautan dan Perikanan. 6(2):131-138.

Sinurat E, Peranginangin R, Saepudin E. 2015. Characterization of fucoidan extracted from Binuangeuns brown seaweeds. International Journal of Chemical, Environmental and Biological Science. 3(4):329-332.

Sinurat E, Kusumawati R. 2017. Optimasi metode ekstraksi fukoidan kasar dari rumput laut cokelat Sargassum binderi Sonder. Jurnal Pascapanen dan Bioteknologi Kelautan dan Perikanan. 12(2):125-134.

Sinurat E, Maulida NN. 2018. Pengaruh hidrolisis fukoidan terhadap aktivitasnya sebagai antioksidan. Jurnal Pascapanen dan Bioteknologi Kelautan dan Perikanan. 13(2): 123-130.

Synytsya A, Kim WJ, Kim SM, Pohl, R, Synytsya A, Kvasnicka F, Copikova J, Park Y. 2010. Structure and antitumour activity of fucoidan isolated from sporophyll of Korean brown seaweed Undaria pinnatifida. Carbohydrate Polymer. 81(1):41-48.

Tapotubun AM. 2018. Komposisi kimia rumput laut Caulerpa lentillifera dari Perairan Kei Maluku dengan metode pengeringan berbeda. Jurnal Pengolahan Hasil Perikanan Indonesia. 21(1): 13-23. 
Thalapaneni NR, Chidambaran KA, Ellappan T, Sabapathi ML, Mandal SC. 2008. Inhibition of carbohydrate digestive enzymes by Talinum portulacifolium (Forssk) leaf extract. Journal of Complementary and Integrative Medicine. 5(1): 1-10.

Vinoth KT, Laksmanasenthil S, Geetharamani D, Marudhupandi T, Suja G, Suganya P. 2015. Fucoidan-a-d-glucosidase inhibitor from Sargassum wightii with relevance to type 2 diabetes mellitus therapy. International Journal Biological Macromolecules. 72:1044-1047.

Wang J, Zhang Q, Zhang Z, Song H, Li P. 2010. Potential antioxidant and anticoagulant capacity of low molecular weight fucoidan fractions extracted from Laminaria japonica. Journal Biological Macromolecules. 46:6-12.

Wang Y, Nie M, Lu Y, Wang R, Li J, Yang B, Xia M, Zhang H, Li X. 2015. Fucoidan exerts protective effects against diabetic nephropathy related to spontaneous diabetes through the NF- $\mathrm{BB}$ signaling pathway in vivo and in vitro. International Journal of Molecular Medicine. 35(4): 1067-1073.
Wang Y, Xing M, Cao Q, Ji A, Liang H, Song S. 2019. Biological activities of fucoidan and the factors mediating its therapeutic effects: a review of recent studies. Marine Drugs. 17(3): 2-18.

Yin X. 2013. In vitro investigation of the inhibitory effect of fucoidan on a-glucoisidase enzyme activity. [Thesis]. Tasmania (AUS): University of Tasmania.

Yuan Y,MacquarrieD.2015. Microwaveassisted extraction of sulfated polysaccharides (fucoidan) from Ascophyllum nodosum and its antioxidant activity. Carbohydrate Polymer. 129: 101-107.

Zhao X, Xue CH, Li ZJ, Cai YP, Liu HY, Qi HT. 2004. Antioxidant and hepatoprotective activities of low molecular weight sulfated polysaccharide from Laminaria japonica. Journal of Applied Phycology. 16(2):111115.

Zvyagintseva TN, Shevchenko NM, Chizhov AO, Krupnova TN, Sundukova EV, Isakov VV. 2003. Water-soluble polysaccharides of some far-eastern brown seaweeds. Distribution, structure, and their dependence on the developmental conditions. Journal of Experimental Marine Biology and Ecology. 294:1-13. 